\title{
Assessment Framework of Building Facade in Optimizing Indoor Thermal Comfort of Green Building Index (GBI) Certified Office Building
}

\author{
Asniza Hamimi Abdul Tharim ${ }^{1}$ and Muna Hanim Abdul Samad ${ }^{2, a}$ \\ ${ }^{1}$ Faculty of Architecture, Planning and Surveying, Universiti Teknologi Mara (Perak), Malaysia \\ ${ }^{2}$ Architectural Programmed, Universiti Sains Malaysia, Penang, Malaysia
}

\begin{abstract}
During the past decade, the construction industry has seen a new trend in the development of "green" or "sustainable" construction concept around the world with vast support from prominent organization, together with the introduction of sustainable building codes. The establishment of green building certification systems worldwide is seen as one of the most efforts in the emerging green building movement. In order to support the development of the "green" and "sustainable" concept in Malaysia, Green Building Index (GBI) was launched by the government on 21 May 2009 that created to promote sustainability in the built environment and raise awareness of environmental issues. However, the construction industry seems to have focused only on findings the "right mechanism" for an environmentally sustainable "final result" in order for the building to be certified as green with the lacking of continuous assessment on the building performance after the certifications. This study is purposely conducted to investigate the performance of various rated Green Building Index (GBI) Non-Residential New Construction office buildings and the influence on Indoor Thermal Comfort (ITC) of the selected buildings. The aim is to develop an assessment framework for optimum green building architectural façade to be used for office buildings in Malaysia as well as to analyse the occupants' perception, satisfaction and performance in the selected Green Building Index (GBI) rated office indoor environment. This research is still in its infancy; therefore the paper is focused on research aims, research scope and methodology, and expected deliverables for the proposed research.
\end{abstract}

\section{Introduction}

Sustainability is fast becoming a global phenomenon with a wide range of professional attentiveness and perspectives. It is believed that the idea of sustainability first emerged 40 years ago [1]. Since then, expansion of the sustainability worldwide continuous to accelerates with the supports from the industries and society [2]. Over the last few decades, a common definition of sustainability has been developed. According to the "United Nations- Our Common Future" [3] sustainability is a concept that incorporates a wide range of social, economic and environmental issues with the idea of responsible stewardship that integrate systems in order for them to meet the needs of present without compromising the future needs. Sustainability comprises of doing good things for environment and

\footnotetext{
${ }^{\text {a }}$ Corresponding author : mhanim@gmail.com
} 
societies that subsidise to the improvement in energy management and conservation, human being social life over and above the nation's economic development. Hence, sustainable development is a dynamic process that incorporates a diversity of levels and balancing scales vacillating from economic and agricultural development to the management of human defrayals, economics, societies, ecological systems and building practices that link to the global concern [4-6]. One of the most significant aspects in nation sustainability in most countries is the construction industry that comprises the sustainable development and construction that also known as the 'green' construction. The sustainable development of the construction industry has been a worldwide crusade that has been growing for the last two decades [7]. Sustainable development has a complex relationship with growth; subsequently the population and economic growth increase the pressure on the environment. Nevertheless, in order to achieve sustainability, the excessive economic growth is involved to attain an adequate level of social development with the quality of life. Therefore, it is crucial to understand the various aspects of sustainable development and how it affects the economics growth by understanding the proper use of environment resources that comprises two main components that are the human physical and nature.

\section{Research Background}

Sustainable in the construction industry is defined as the degree of growth and expansion that fulfil the need of the current state of development without compromising the need for future generations [8]. Hence, the construction industry often being accused of contributing to the negative impact towards the world environment in a most of the aspects, ranging from excessive consumption of resources to direct environment pollution [9] include climate change, ozone exhaustion, forfeiture of biodiversity and many others [7]. Therefore, implementation of sustainable development in the construction industry is seen as the best way to address, reduce and eliminate these interrelated problems in order to conserve the environment for the sake of future generation and planet [10]. However, [11] raise concern about the sustainable and buildability of the construction industry are key elements in building design that are typically governed by laws and regulations that may differ from country to country thus creating barriers to complete and standard implementation of sustainable construction in worldwide. Previous studies by various researchers believed that the market for sustainable buildings is increasing as the people in the construction industry has acknowledged that sustainable in construction industry may ease the negative impacts on the environment and bring significant improvement to the social and environmental benefits of all nations worldwide [12-14]. Therefore, as more owners and clients seek to develop sustainable buildings, the construction industry is adapting to new requirements in order to meet owners' concerns. Recently, a significant change in the construction industry has been the increased interest in green design and sustainable materials. Sustainable materials are the potential resource to mitigate the impact on the environment and bring significantly and holistic benefits [15].

Similarly, the development and introduction of sustainable building codes is taking place around the world with vast support from prominent organization [16]. The ICC define building codes as the code that "provide reasonable controls for the design, construction, use, occupancy and maintenance of buildings and their facilities and various components" [17]. Thus, the establishment of green building certification systems worldwide be seen as one of the significant efforts among the numerous efforts in the emerging green building movement, it is also believed to be one of the most prominent and guarantees systematic approach to continuing countries effort toward promoting sustainable environment [18]. The first green building standard was introduced in United Kingdom (UK) known as the Building Research Establishment Environmental Assessment Method (BREEAM). Since then several country have developed their own green standard [19], including the Leadership in Energy and Environmental Design (LEED) of the United State of America (USA), Comprehensive Assessment System for Building Environmental Efficiency (CASBEE) Japan and Green Star Australia [20]. Consequently, as an acceleration of the Malaysian sustainable construction industry and as a manifesto of the government's seriousness in implementing "green" initiatives for the country, The National Green Technology Policy was launched by the Former Prime Minister of Malaysia Tun Dr 
Mahathir Mohamed in July 2009 with the aim to be a driver to support the national economy and promote sustainable development in Malaysia. In order to expand the use of green technology in Malaysia, Green Building Index (GBI) was launched by the government on 21 May 2009 and it is one of the incentives announced in Budget 2010 under the heading of "Promoting Construction of Green Building". The Green Building Index (GBI) is a green rating index on environmentally friendly building with the ability to save utility costs and preserve the quality of the external and internal environment. Therefore, it is crucial for the sustainable construction not only focused on environmental sustainability but also integrations of all aspects that can contribute to improved health, satisfaction and wellbeing amongst building users [21]. Some research suggests that occupants in environmentally sustainable buildings feel better psychologically, although this area of research is in its early stages. The construction of green and sustainable buildings has increased due to increasing level of awareness on the sustainability issues around the worlds with the aims to reduce the negative environmental impact to building indoor space and increase occupant's satisfaction [22, 23].

\section{The Issue of Indoor Thermal Comfort and Green Rated Building}

Malaysia is classified to have tropical climate condition that are mainly hot and humid throughout the year. Normally the first six months will be sunny months and the second half of the year will be the wet months. Szokolay [24] described the tropical climate of hot and humid as one of the extreme and hardest climate to compromise in term of the building design. The after effect of global warming that the world is facing today is the increase in outdoor and indoor temperatures. Although climates, living conditions and cultures differ widely throughout the world, the temperature that people choose for comfort under similar conditions of clothing, activity, humidity and air movement has been found to be very similar. To date, however the construction industry seems to have focused only on finding the "right mechanism" for an environmentally sustainable "final result" such as energy efficiency or water conservation in order for the building to be certified as green with the lacking of continuous assessment on the building performance after the certifications [25].

The primary objective of a building is to provide shelter, space and comfort for the people to live, work and interact with them [26]. In this respect, it is worthwhile to consider and take into account the role of building façade as not only being a wrapper of a building but also a barrier with various vital functions that influence the indoor environmental quality and comfort [27]. Often the achievement of Indoor Thermal Comfort (ITC) in buildings is determined by the thermal performance of façade [28 and 29], to a large extent ranking second under local climate characteristic. The question raised is how far the building façade affects indoor thermal performance is conducted for the mechanical ventilation buildings in hot and humid country of Malaysia? Research on this matter has been conducted by various researchers in different aspects. Earlier research conducted by [30] found out that thermal comfort is affected by the thermal interaction between the building and external environment. Researcher [31] had conducted research on the impacts of architectural components on energy consumption in mechanically ventilated building as well as its health related effects on the performance of building occupants. Although there were many research conducted on the effects of external building envelope and its influence to the indoor air quality, intelligent façade design solutions in hot and humid climate have been barely studied compared with those in cold climate [32].Nevertheless, a variety of green building certification systems had been introduced worldwide but one question remains to be clarified: are the scheme currently applied in green building certification fostering buildings of Indoor Environmental Quality satisfying their occupants? [33]. Gou et al. [34] suggested the need of research in the involvement of additional factors influencing the indoor air quality satisfaction of occupants to be conducted in tropical countries. It is vastly believed that the green building can provide a better indoor environment that contributes to health, wellbeing and user's productivity and performance. If these green building are designed well, it can increase comfort and create healthier working conditions. 


\section{The Proposed Research}

The main aim of this proposed research by the author is to develop assessment framework on the selection of architectural building facade to be used as a construction façade guideline for office buildings. This study also intended to examine the objective and subjective measurements of overall post- occupancy thermal comfort in a Non-Residential New Construction (NRNC) Green Building Index (GBI) [35] rated office building with different types of building façade in hot and humid country of Malaysia to achieve overall thermal comfort of the internal environment as well as to identify on the correlation of these architectural building façade heat radiation with the satisfaction level of occupants in post occupied green office building in Malaysia. However this research will not touch on the aspects of the energy efficiency or the Indoor Environment Quality (IAQ) of the selected green rated office buildings, but will focus more the correlation between the objective and subjective measurement of the Indoor Thermal Comfort (ITC) of the working space. Extension empirical research on indoor Thermal Comfort in hot and humid climate in various green aspects is not new in this country, thus the study on the impacts of façade to building indoor thermal comfort remains relatively new in Malaysia. Therefore this study intended to:

i. Measure both on objective and subjective parameters of rated Green Building Index (GBI) office building Indoor Thermal Comfort (ITC)

ii. Study on Non- Residential New Construction Green Building Index (GBI) rated office building in Malaysia

iii. Covering various types of green building façade

As for the hypothesis, it is assumed that the Green Building Façade (GBI) certified buildings will be able to reflect the ultimate thermal comfort in the building indoor space compared to the uncertified Green Building Index (GBI) buildings in Malaysia. It is also predicted that the occupants (employees) in the certified office buildings should be in the most satisfaction conditions while working in the buildings. The scope of this study focuses on the measurement of Thermal Comfort in a working space of a Green Building Index (GBI) rated office building in Malaysia. Thermal comfort measurement will cover both the objective and subjective parameters. Objective measurement will be done by using the fieldwork equipment measurement of the indoor temperature, relative humidity, air velocity and heat radiation, while the subjective measurement will be conducted by questionnaire survey to the selected building occupants that will covers the aspects of user's perception and satisfaction in five offices building with different architectural façade. The questionnaire survey covers the demographic profile of building users and their perception and satisfaction on four main aspects of the Indoor Thermal Comfort (ITC). The proposed research project is purposely to be conducted in the state of Kuala Lumpur. The study will focus on various Green Building Index (GBI) rated Non- Residential New Construction Office Building for comparative studies on the best selection of green building architectural facade. There are two types of sampling used for this proposed research project; Random Sampling for the subjective measurements (questionnaire survey) and Selected Sampling for the objective measurements.

\section{Significant of the Proposed Study}

This study adds to the existing body of knowledge by examining the contribution of different building façade radiation transmitted to the indoor space of building. In additions this study will be the benefits reference for architect (designers) and developer in constructing good indoor thermal comfort building through the implementation of suitable building façade for hot and humid country like Malaysia that helps to ease the process of obtaining green building certifications in this country. 


\section{References}

[1] W.M. Adams, The future of sustainability: re-thinking environment and development in the twenty-first century, report of the IUCN renowned thinkers meeting, (2006). $<$ Retrieved from http:// cmsdata.iucn.org/downloads/iucn_future_of_sustanability.pdf $>$

[2] C.J Kibert and M.E. Rinker, The next generation of sustainable construction, Building Research and Information, 35(6), 595-601, (2007).

[3] United Nations, Report of the world commission on environment and development: Our common future, (1987). <Retrieved from http://www.un-documents.net/wced-ocf.htm>

[4] B. Givoni, Climate Consideration in Building and Urban Design, Van Nostrand Reinhold, New York, (1998).

[5] P. Bansal, Evolving sustainably: a longitudinal study of corporate sustainable development, Strategic Management Journal, 26(3), (2005).

[6] P.R. Berke and M.M. Conroy, Are we planning for sustainable development, Journal of the American Planning Association, 66(1), (2000).

[7] C.J. Kibert, Sustainable Construction: Green Building Design and Delivery, John Wiley and Sons, New Jersey, (2008).

[8] F. Duchin, Global Scenarios about Lifestyle and Technology, the Sustainable Future of the Global System, United Nations University, Tokyo, (1995).

[9] G.K.C Ding, Sustainable construction - the role of environmental assessment tools, Journal of Environmental Management, 86(3), 451-64, (2008).

[10]T. Waas, A. Verbruggen and T. Wright, University research for sustainable development: definition and characteristics explored, Journal of Cleaner Production, 18(7), 629-636, (2010).

[11]M. Duris, I. Nemec and M. Polak, Buildability and sustainability - a question of professional responsibility, International Congress - Global Construction: Ultimate Concrete Opportunities, Dundee, (2005).

[12]W. Wang, R. Zmeureanua and H. Rivard, Applying multi-objective genetic algorithms in green building design optimization, Building and Environment, 40(11), 1512-1525, (2005).

[13]R. Ries, M. Bilec, N.M. Gokhan and K.L Needy, The economic benefits of green buildings: A comprehensive case study, The Engineering Economist, 51(3), 259-295, (2006).

[14]C. Thormark, The effect of material choice on the total energy need and recycling potential of a building, Building and Environment, 41(8), 1019-1026, (2006).

[15]L. Florez, D. Castro and J. Irizarry, Measuring sustainability perceptions of construction materials, Constr. Innovation, 2(4), 217-234, (2013).

[16]G.B. Hanna, Energy efficiency building codes for Egypt, Journal of Energy and Power Engineering, 5(12), 1134-1141, (2011).

[17] International Code Council, Building Department Administration, ICC Publications, Country Club Hills, (2007).

[18]H.H. Liang, C.P. Chen, R.L. Hwang, W.M. Shih and S.C. Lo, Satisfaction of occupants toward indoor environment quality of certified green office buildings in Taiwan, Building and Environment, 72,232-242, (2014).

[19]V. Potbhare, M. Syal, M. Arif, M.M.A. Khalfan and C. Egbu, Emergence of green building guidelines in developed countries and their impact on India, Journal of Engineering, Design and Technology, 7(1), 99-121, (2009).

[20]A. Zimmerman and C.J. Kibert, Forum informing LEED's next generation with the natural step, Building Research and Information, 35(6), 681-689, (2007).

[21]A. Smith and M. Pitt, Sustainable workplaces and building user comfort and satisfaction, (2011).

[22] S. Korkmaz, M. Horman, K. Molenaar and D.Gransberg, Influence of project delivery methods on achieving sustainable high performance buildings, Research Sponsored by the Charles Pankow Foundation, DBIA, (2010). <available at: www.dbia.org/NR/rdonlyres/ F15664D5-B617-487C9C95-EE4F5E453A9D/0/CPF_ThrustII_05212010_Final.pdf.>

[23] Green Building Council of Australia, Green star overview, (2011). <available at: www.gbca.org.au/green-star/green-star-overview/> 


\section{MATEC Web of Conferences}

[24] S.V. Szokolay, Introduction to Architectural Science: The Basis of Sustainable Design, Elsevier, (2008).

[25]J. Yang, Editorial: promoting integrated development for smart and sustainable built environment, Smart Sustain. Built Environment, 1(1), 4-13, (2012).

[26]M. Bessoudo, A. Tzempelikos, A.K. Athienitis and R. Zmeureanu, Indoor Thermal Environmental Conditions near Glazed Facades with Shading Devices, Part 1: Experiments and Building Thermal Model, Building and Environment, 45, 2506-2516, (2010).

[27]S. Drake, The Third Skin: Architecture, Technology and Environment, UNSW Press, Sydney, (2007).

[28]E. Gratia and A. De Herde, Is day natural ventilation still possible in office buildings with a double-skin façade?, Building and Environment, 39(4), 399-409, (2004).

[29] W. Liping and W.N. Hien, The impacts of ventilation strategies and facade on indoor thermal environment for naturally ventilated residential buildings in Singapore, Build. Environment, 42(12), 4006-4015, (2007).

[30]A.P. Gagge, A.P. Fobeles and L.G. Berglund, A standard predictive index and human response to the thermal environment, ASHREA Transactions, 92(2), 709-731, (1986).

[31]C.K. Cheung, R.J. Fuller and M.B. Luther, Energy efficient envelope design for high rise apartments, Energy and Buildings, 37(1), 37-48, (2005).

[32]C.E. Ochoa and I.G. Capeluto, Strategic decision- making for intelligent buildings: comparative impact of passive design strategies and active features in hot climate, Building and Environment, 43, 1829-1839, (2008).

[33]H.L. Han, P.C. Chen, L.H. Ruey, M.S. Wen, C.L. Shih and Y.L. Huey, satisfaction of occupants towards indoor environment quality of certified office building in Taiwan, Building and Environment Journal, 72, 232-242, (2013).

[34]Z. Gou, D. Prasada and S.Y. Lau, Are green buildings more satisfactory and comfortable?, Habitat Int., 39, 156-161, (2013).

[35]Buildings, GBI, (2013). 